\title{
The Development and Demise of Child Labour in a Javanese Tea Plantation, 1900-2010
}

\author{
Pujo Semedi; Gerben Nooteboom \\ Universitas Gadjah Mada, Indonesia; University of Amsterdam, The Netherlands \\ Corresponding Author: pujosemedi@ugm.ac.id; G.Nooteboom@uva.nl
}

\begin{abstract}
Child labour used to be a common phenomenon in colonial tea plantations at the start of the $20^{\text {th }}$ century. Since the 1970s, however, child labour started slowly to disappear from tea plantations on Java. In this article, we argue that the abolishment of child labour was never the result of improved legislation, but should be understood as part of several interrelated historical processes. Emerging educational opportunities for boys and girls, changes in labour demand, household strategies, diversification of family incomes, ideas on childhood, and technological changes in the production process are key to explain this change. This observation might raise serious considerations for policy makers today who aim to abolish child labour or improve working conditions of children.
\end{abstract}

Keywords: Java; colonial plantation; socio-economic; child labour; migration

\section{INTRODUCTION}

Almost from the onset of the establishment of tea plantations on Java, children took part in the labour process from an early age. In a context of general labour shortage, the plantation management actively tried to lure complete families to the plantation in an attempt to secure a stable and loyal labour force. ${ }^{1)}$ From about eight years old, both boys and girls, were considered able to perform light and simple tasks such as cleaning trunks of tea shrubs, sorting leaves or tea in the factory, light weeding, gathering seeds, or collecting caterpillars and harmful insects. Besides taking these tasks, girls were expected to fulfil household chores such as cooking and babysitting to enable their mothers to work. Children fell automatically under the labour arrangements of their parents, but could earn small additional incomes for work at the plantation.

When children got older, they slowly engaged in heavier tasks and at the age of about 12 till 14, both girls and boys were considered full labourers. Most girls married before the age of 15 . Both from the perspectives of parents and from the plantation management, it was considered normal and logical to include children in the plantation work as family labour was included in agriculture in general (White 2012: 81). Universal schooling was not yet provided and labourers were scarce. At the early $20^{\text {th }}$ century, only two percent of the indigenous population of Indonesia received some form of formal educationmostly children from the indigenous elites (White 2004: 90).

For the parents of today's children, to work outside school was completely normal. Most of the grandparents of today's plantation children did not go to school, or only for a few years, for them, it was common to work in agriculture or at the plantation (see White 2012: 81). Since the 1970s, however, child labour started slowly to disappear from the tea plantations on Java. In the early 2000s, almost no children are found working in the tea plantations anymore (Wal 2008) with an exception for plantations in East Java where girls tend to marry young (below the 
age of 14 or 15) and no longer are considered children (Jones 2001). How did this change come about and what lessons on the emergence and disappearance of child labour and policy can be learned from this historical study?

Throughout this article, we speak of child labour. Although child labour has become a highly loaded term, often synonymous with abuse and exploitation (Lieten and White 2001: 10), we do not necessary refer to the worst forms of child labour. With child labour, we mean the direct and indirect productive and waged activities of children below the age of 16 including work with parents in agriculture or at estates, individual waged work, household chores and babysitting to enable mothers to work. Studies on plantation hardly mention anything about the involvement of children in the plantation agricultural system. Archival data on this topic is sketchy, thus many of the information here on working children are based on oral history. Between 2000 and 2009, for this purpose, a large number of retired plantation workers-most of them women-have been interviewed.

\section{CHILD LABOUR IN INDONESIA}

The use of children's labour force was considered usual in agriculture and also has to do with ideas on childhood and adulthood (White 2012). In this respect, in plantations, the situation was not much different than elsewhere in agriculture. Children were supposed to work with their parents to keep the household running and in cases of coolie labour or indentured labour, sometimes whole families migrated and were considered a welcome addition to the workforce in the largely underpopulated plantation areas. If the plantation management was able to contract a couple to work for them, this automatically included the workforce of the children.

In the second half of the $19^{\text {th }}$ century, the early years of the plantation economy in Asia and Southeast Asia, child labour at the plantations was often part of constellations of unfree labour forms in which parents were lured to work in the plantations by brokers promising good wages and giving cash advances (Baak 1997: 436-37). Children were explicitly part of these labour arrangements and followed their parents in bondage. In the Dutch Indies, on the plantations of Java and Sumatra, this situation was not much different (Breman 1983, 1987, 1988; Breman and Daniel 1992).
Attracting labourers to the plantations was a difficult task as labourers were often reluctant to come to the remote plantations and enter unfree labour contracts or fulfil them till the end. Other means had to be employed. Practices as using opium addictions, pre-payments, coverage of gambling debts, capture, law enforcement and promises of huge wages and a large credit in return of a labour contract were common practice (Breman 1992). Moreover, once contracted and working at the plantations, planters used multiple means to reduce the chance of debt repayment by the workers. Examples in the literature of means to keep labourers indebted mentioned among others: underpayment, consumption debts at plantation shops, the organisation of gambling and prostitution, and a steady supply of opium (Breman 1987, 1992). Even after the abolishment of slavery and the coolie system towards the end of the $19^{\text {th }}$ century, plantation labour remained largely unfree by today's standards. ${ }^{2)}$

Historical sources on children in these labour arrangements in agriculture and agricultural estates and plantations are rather scarce. White (2004: 789) signals a historical bias towards working children in industry, factories and mines and a stereotypical interpretation of the history of child labour in which urbanisation and industrialisation are seen as the main causes of the mass exploitation of child workers and legal means as major instruments of its elimination. In the colonies, industrial child labour was never that important and mass employment of children occurred in agriculture instead. According to White: "Child labour [in Indonesia] historically has been primarily a nonindustrial, and certainly a non-factory phenomenon" (ibid). At the turn of the century - somewhat late if compared to the establishment of child labour laws in homeland Holland - the first discussions on child labour laws in the Netherlands Indies appeared. ${ }^{3)}$ It would take until 1925 before official legislation on child labour was approved (2004: 79).

In these early years of labour legislation, attention for the education of indigenous children was a much more important element. As a result of the Ethical Policy, and increased attention for the hardship and poverty of the local population, the first schools for local people were established in 1907. The number of desa schools rapidly increased in the following two decades (White 2012: 84). It was only in 1919 schools were established in plantation areas but very few of them actually provided education facilities to the children of lower plantation workers of the lower ranks (White 2004). Most plantation schools were 
only established long after the Second World War and Indonesian independence. Plantation owners apparently had little interest in establishing schools at their domains as young labourers were a much needed additional workforce in the often sparsely populated plantation areas.

In 1925, influenced by the ILO convention of 1919 on minimum ages for industrial workers and the wide approval of this convention in countries like Japan, The Philippines and British India in 1923, the governing council of the Netherlands Indies (Volksraad), approved a modified version of the 1919 ILO convention. ${ }^{4)}$ In this labour law, the minimum age for children in industrial enterprises in the Netherlands Indies was defined as 12 years and, in line with most other colonies, many economic sectors were exempted. ${ }^{5)}$ The law only applied to industrial activities such as mining, manufacturing, construction and transport. Agriculture, small enterprises, home industries, trade and the service sectors were excluded.

The general trend in the following years was the gradual abolishment of child labour from factories, but sectors in which most children were working, such as tobacco, sugar cane production and the coffee and tea estates, remained untouched. Plantation owners were generally against the abolishment of child labour due to the labour shortage in their plantation areas. Reports of 138 sugar estates cited by Levert (1934: 126 , in White 2004) mentioned the use of as much as 23 percent 'half-half adult labour in their sugar plantations in 1926 - probably boys only. It is likely, that figures in the tea plantations were similar or even higher during those years as tea plantations employed large numbers of children and could use both boys and girls. These children could earn up to 10 cents a day (an equivalent of over 3 kilo's of rice in 1920). These wages were relatively high and children added to the prosperity of their parents rather than being employed out of poverty. Child labour in plantations did not decrease substantially before WOII.

In 1948, the Republican government of Indonesia passed a new labour law (re-enacted in 1951) which included a total prohibition on employment of children under 14. This act, however, contained the provision that the enactment of some articles could be postponed (White 2004). Again, the new regulations did largely not apply for the plantation sector and agriculture in general. The 1951 law remained rather ineffective and in practice the 1925 ordinance remained in force. It would last until 1997 before new legislation on labour and child labour would pass the parliament. As we will see, more important was the 1984 law on compulsory education. Again education policies preceded labour laws.

Notwithstanding the poor labour laws, between 1951 and 1997, mass child labour gradually disappeared from the plantations and when finally the new legislation was translated into regulations (in 2001 and 2004) child labour has virtually gone from plantation. In the following paragraphs, we will return to the issue of working children and show from within plantation life how labour has been controlled over the years and how the change from mass employment of children to a formalised legalised labour regime without any working children has come about at the Jolotigo tea estate in Central Java.

\section{HISTORY OF JOLOTIGO PLANTATION LABOUR}

Jolotigo was established as a coffee plantation by Johannes van Hall, a government agricultural controller who turned planter in 1875. After 23 years in operation, the coffee cultivation was proven to be a failure and Jolotigo was sold to the new owner August Johannes Doorman who transformed the plantation into a tea and cinchona ${ }^{6}$ estate. Later on in the 1920s Jolotigo acquired new parcels of land, leased for 75 years from the government. In the lower parts of the plantation, rubber was cultivated. During the nationalisation of the foreign-owned plantation companies in 1957, Jolotigo ownership was transferred to the State Plantation Company of the Government of the Republic of Indonesia (PT Perkebunan). In the beginning, the State Plantation Company (PN) operated more or less like a government service and aimed to offer work to as many as possible people, but since the late 1970s, the plantations gradually changed into professional business companies aimed to generate profit.

From period to period, the structure of the Jolotigo labour force has been changing, but its three major levels remained the same; plantation management, plantation personnel (officials and workers officially employed), and labourers with or without temporary labour contracts. In the early days this three-layered structure simply consisted of Indonesian labourers, coolies and foremen with Dutch overseers and administrators as management staff. Later on in the 1910s the Dutch staff obtained a fixed status as plantation employee with retirement benefit and other privileges, foremen together with 
technicians and administrative clerks obtained a lower status as regular labourer with fixed monthly wagesbut without retirement benefits, while the coolies remained much lower as hired labourers who got paid only when they worked - either on daily wages or by piece rate. All working children fell in this category.

After the 1957 nationalization of the plantation, these labourers were further classified into seasonal, daily and formally employed labourers. In the 1990s the seasonal labourer was called - politically correcttemporary worker, karyawan lepas borong, the daily labourer was called regular daily worker, karyawan harian teratur, and the formally employed labourer became simply a worker, karyawan. Overseers and above were termed as 'management staff', karyawan pimpinan. Children were not officially mentioned in the plantation records and could never get a formal contract, but, in practice, they joined as temporary worker from early age listed under the name of their mother or elder sister.

\section{Plantation Labour at the End of the 19th \\ Century}

At the turn of the $19^{\text {th }}$ century, Javanese coolies might be roughly classified as indentured labourers, free labourers with a contract, free labourers without a contract, and free labourers of contractor companies (Koperberg 1917). ${ }^{7)}$ Most of plantation coolies in Java were native Indonesians who took the plantation job on their own will. However in practice, they were often victims of native Indonesian foremen who roamed around the countryside to recruit labourers. They often lured and tricked villagers into plantation work. They formed and led them as a working gang with high internal control, postponed payments and applied harsh sanctions when workers tried to escape or performed badly. Overseers and the administrator who were Dutch worked under a written contract with the plantation company and they assigned the dirty work of labour recruitment largely to the foremen.

From the plantation company's perspective, it would have been far more advantageous if farmers in the surrounding villages were willing to work on a regular basis in the plantation. But the farmers in the Jolotigo area were reluctant to do so. In the villages they were master of their own labour, while in the plantation they would be degraded into a coolie. At most, they were willing to work in the plantation as a seasonal worker during the idle period between planting and harvesting rice. Moreover, they preferred to be paid by piece rate. ${ }^{8)}$ In this way they could arrange their schedule and decide when to work at their own farm or in the plantation. This arrangement was fine with the plantation management as far as it was related to seasonal works such as harvesting and processing coffee (Angelino, 1936: 20). For regular tasks, such as weeding, fertilizing, pruning, guarding and horse minding, the plantation was in dire need of a regular labour supply. For these routine jobs, a regular labour force must be maintained and labour had to be recruited from elsewhere.

The earliest Jolotigo's regular labour force, consisted of a small number of foremen and bachelor coolies, kuli budjang, who were recruited from the lowland areas of Pekalongan that were widely marked by landlessness and unemployment (Knight 1993a; 1993b). Most of the time, these youths were dregs of their society; poor, petty criminals, thieves and gamblers. Their choice was either to stay in their home village and sooner or later get into trouble or to go to the isolated plantation up in the hill to amend their poor socio-economic condition (cf. Galenson, 1984; Emmer 1986). In the eyes of the landless and unemployed bachelors, the lonely plantation was a save harbour compared to the economically difficult situation in their home villages. The geographical isolation and enclave social life of the plantation was not a problem, for some it was even a blessing. Here live was sure, they got dependable income and a fixed roof to sleep under (cf. Wertheim, 1956: 242).

\section{Gamelan and Slametan}

Exact numbers of kuli budjang in the early years of Jolotigo are not available, but already by 1883 , the plantation emplacement, Puwoko, was inhabited by the administrator, an overseer, eighteen foremen and their families and a large number of budjang coolies who lived in 4 large and 12 small houses plus a barrack. In the course of the decade, more regular labourers came to Puwoko and more women arrived. In 1886, a special barrack was established for female labourers, by 1890 the labourers' living quarters were expanded 19 meters in length, and by September 1891 the plantation employed 131 male labourers, 72 female labourers and less than ten foremen. ${ }^{9)}$ Children are not mentioned in the records of the plantation, but it is likely that in this period children came to work with their mothers and others in the plantation fields.

The plantation was very dependent on a steady supply of workers. Aware of this fact, the Dutch administrator and overseer treated the Javanese delicately and tried to attach labourers to the plantation 
by all means. They presented themselves as benevolent but strict patrons who did not mind to resort into harsh disciplinary action. At the same time, they provided means for the workers to spend their money, such that they would need to keep on working.

To keep the foremen and coolies content, the plantation bought a set of Javanese music instruments, gamelan, to be played in ronggeng dancing sessions which often were associated with prostitution. The plantation management was also involved, or at least willing to facilitate, the plantation labourers' traditional rituals and slametan - Javanese communal feasts to commemorate important events such as circumcision, wedding, and death (Geertz, 1973: 147; Van den Berge, 1998: 34-35). A market came three times a month in the pay day. Prior to a pay day, traders of almost any kind entered the Puwoko emplacement with bundles of merchandise, and along with the traders came the gambling masters and ronggeng dancers. All were more than willing to take a share of the labourers money.

Compared to other plantations in the area he staff and labourers of Jolotigo plantation were relatively well paid. The high wages of Jolotigo foremen were probably related to the scarcity of hands in the area and successful negotiation of foremen. In the 1880 s, on an average, the plantation company spent $f 2.238$ annually on foremen' wages. Upon finding this fact, P.H. Soeter, an NHM inspector who was sent to check Jolotigo in November 1890, angrily reported that "Jolotigo personnel were outrageously overpaid". In response to the report, the company cut the number of foremen to around 6 persons with a monthly wage of $f 8$ (from $f 20) .{ }^{10)}$ The same wage cut also applied to Jolotigo's kuli budjang down to the level of $f 1,25$ per month or five cents per day. ${ }^{11}$

\section{THE DEVELOPMENT AND DEMISE OF CHILD LABOUR}

In the development and institutionalisation of child labour and its demise in the late $20^{\text {th }}$ century we observe four periods: 1) the prosperous period (1900 - 1930); 2) stagnation and decline (1930 - 1942); 3) wartime, turmoil and famine (1942 - 1970); and 4) schooling, technological change and the opening up of the plantation economy (1970 till now). These periods of changing labour regimes correspond roughly with developments described elsewhere in studies on plantations and rural labour (Baak 1997; Breman 1983, 1987; Breman and Daniel 1992; Breman 1988; Collier 1981).

\section{The prosperous era (1900-1930)}

The transformation of Jolotigo into a tea plantation in 1898 increased the demand of labour and radically changed the gender structure of the plantation labour force. Cultivation of tea requires a much higher number of labourers than coffee and cinchona. Harvesting tea-picking the young shoots and leaves-has to be done on a regular basis and must be done all year round. Every seven to ten days, the young leaves need to be picked. Also the labour intensive tea processing must be carried out everyday, all year round (Plomp, 1993: 24 - 30). As a result, the plantation needed a constant pool of labour to be able to harvest the fields in rotation and to process the crop. Weeds grow faster in tea fields and intensive and regular weeding is required. In the tea processing plant, male labourers did the crude and heavy work, while women processed and sorted the tea - the delicate task of final grading by manually winnowing the dried tea into several qualities. Tea, was prone to more pests_leaf blight, caterpillars and damage by many kind of insects. Pests had to be thoroughly controlled to protect young leaves from damage. For the labour intensive means of pest control, such as catching caterpillars and insects by hand, as well as sorting out affected leaves, the cheap labour of women and children was used.

By 1900, there were more than two hundred casual labourers recruited from Jolotigo's neighbouring districts such as Kajen, Karanganyar, Bojong, Comal, Paninggaran, Banyuputih; as well as in other regencies of Wonosobo, Temanggung and Kendal, who worked all year round in Jolotigo. More than half of these labourers were female. ${ }^{12)}$ A good number of those female labourers came from hamlets next to the plantation. It seemed that as early as the 1910s, Jolotigo farmlands were no longer sufficient to accommodate the whole village population and villages searched for alternative sources of income. By end of the 1910s, Jolotigo's full time labour force consisted of more than 400 persons, male and female or children not calculated. Daily wages at this period were between $f 0,20$ to $f 0,80$ for foreman and $f 0,18$ to $f$ 0,35 for casual labourers (KV, 1910, Bijl. ZZ).

Tea fields are prone to attacks of several pests. Caterpillars devour mature leaves, while insects suck the sap of tea buds causing dried and dying shoots. A routine, all the year round regime of pest control has to be exercised. In the beginning not enough labour was available to handle this work. The plantation company solved the problem by giving the pest control job to the children of plantation labourers, of 8 till about 
12 years old, under supervision of a pest control foreman. ${ }^{13)}$

The children's job in pest control was picking caterpillars and insects manually, nguler and nglembing. Grandma Wi recalled her experience:

At the beginning, I was afraid of the caterpillars we had to pick. Some of them could hurt and be very itchy when we touched them. They had to be pinched from the leaves with bamboo sticks. But I was brave, not like some of the other girls who were too scared. Some of these girls therefore preferred to work only at the teagarden to collect seeds or joined the cleaning work. I carried on and was even faster than the boys. Most of the money, I gave to my mother, but I had money left to buy sweets or candy.

Work started at six in the morning. With their fellows and breakfast packet, the children went directly to the block of tea that had to be cleaned that day. In the tea field they checked the shrubs one by one meticulously. Whenever they came across rolled leaves, they opened the caterpillar infested leaves, took the animal out, crushed it and put it in a bamboo tube. Hairy caterpillars were taken with a bamboo pincher, as they could hurt or cause itching. Children were children, so they combined their work with playing and joking with their friends, although the foreman kept calling them back to duty, his hand raised menacingly. At nine in the morning, they took a thirty minute break for breakfast, and then work continued until one o'clock in the afternoon. At the end of the working day, they collected the result of their work at a spot where the foreman had lighted a fire, the catch was counted and finally they burned.

Other jobs available for the children were cleaning the stems of tea shrubs from moss and the collection of tea seeds. Moss cleaning was carried out after a block of tea field had been pruned, once in every four years. One by one, the tea shrub stumps were cleaned from moss and parasitic ferns with the help of a dull sickle. Tea seeds were collected to produce seedlings for further expansion of the tea fields or to replace dead shrubs, and for sale to other tea plantations all over Java. For this purpose, two blocks of tea fields, in Sinanas and Kebonmanis were specially cultivated to produce tea seeds, glendheng. Tea shrubs in these blocks were permitted to grow to their full height of six or seven meters and were neither picked nor pruned. From time to time they blossomed and produced seeds. After maturation, the fruits fell to the ground. Children collected the fallen seeds in a light metal container, blik, and then brought them to the factory for further selection and sprouting.

\section{Early Legislation, Crisis and Continuation 1930-1942}

For tasks such as pest control, cleaning and seed collection, Jolotigo boys earned 5 cents a day, and girls earned 3 cents in 1930. The wage was paid once in ten days, 3 times a month, and each child received a sum of money according to the amount of days worked. A diligent boy who had never been absent might receive up to 50 cents ( $f 1,50$ per month), and a girl 30 cents $(f 0,90$ per month). Compared to the earnings of adult labourers, these children's wages were small. The average earnings of a foreman were 35 cent per day, or $f 10.5$ per month. The average wage among female tea pickers in Java during that period was between $f 0.50$ to $f 1$ per 60 kilogram fresh leaves. On an average a tea picker could collect 20 to 25 kilograms leaves per working day (Van Keesteren, 1931). Around 1930, a Jolotigo tea picker earned on average between $f 5$ to $f 9$ per month. Considering that the price of low quality rice at that period was around 3 cents per kilogram, the children's wages in Jolotigo were not bad at all - on an average their monthly earnings could be an equivalent to $45 \mathrm{~kg}$ of rice for a boy and $30 \mathrm{~kg}$ for a girl. This amount was well above the poverty line in Java - which half a century later was estimated by Sajogyo (1996: 3) at $240 \mathrm{~kg}$ / per capita per year, or $20 \mathrm{~kg}$ per capita per month. ${ }^{14)}$

Average standard wages for female contract labourers (not tea pickers) in the Central Java tea plantations at this period were one third of those of male regular labourers and children earned half (boys) or one third (girls) of the female labourers. The common view at that time was that it is alright for women to receive lower wages than men because their role as income seeker was secondary to that of their husband (cf. Knight, 1993b). Even the government Labour Commission, which was quite progressive for that time, proposed that female labourer wages could be pushed down to $20 \%$ below those of male labourers (De Arbeidcommissie, 1920: 14-15; 38). From the perspective of the plantation company, the employment of as much as possible women and children was just the right thing to achieve the company's ultimate goal of a maximum profit (cf. Sajhau and von Muralt, 1987: 120). 
Table 1. Plantation's expenditures on Jolotigo labour, 1928-1939 in guilders $(f)$

\begin{tabular}{|c|c|c|c|c|c|c|c|}
\hline \multirow{2}{*}{ Year } & \multicolumn{7}{|c|}{ Labour costs in guilders $(f)$} \\
\cline { 2 - 8 } & Male & $\%$ & Female & $\%$ & Children $(<12)$ & $\%$ & Total \\
\hline 1928 & 16,852 & 52.62 & 12,879 & 40.21 & 2,295 & 7.17 & 32,026 \\
\hline 1929 & 20,803 & 54.19 & 15,134 & 39.42 & 2,455 & 6.39 & 38,392 \\
\hline 1930 & 15,858 & 52.47 & 12,945 & 42.83 & 1,420 & 4.70 & 30,223 \\
\hline 1931 & 11,455 & 49.54 & 11,305 & 48.89 & 365 & 1.58 & 23,125 \\
\hline 1932 & 14,734 & 53.49 & 12,317 & 44.72 & 492 & 1.79 & 27,543 \\
\hline 1933 & 17,072 & 61.30 & 10,265 & 36.86 & 512 & 1.84 & 27,849 \\
\hline 1934 & 19,346 & 56.29 & 14,481 & 42.13 & 544 & 1.58 & 34,371 \\
\hline 1935 & 14,034 & 52.01 & 11,031 & 40.88 & 1,918 & 7.11 & 26,983 \\
\hline 1936 & 19,910 & 59.51 & 12,863 & 38.45 & 683 & 2.04 & 33,456 \\
\hline 1937 & 11,606 & 45.11 & 12,188 & 47.37 & 1,934 & 7.52 & 25,728 \\
\hline 1938 & 14,463 & 46.56 & 15,008 & 48.31 & 1,593 & 5.13 & 31,064 \\
\hline 1939 & 11,837 & 40.72 & 14,960 & 51.46 & 2,272 & 7.82 & 29,069 \\
\hline Total & 187,970 & 52.24 & 155,376 & 43.18 & 16,483 & 4.58 & 359,829 \\
\hline
\end{tabular}

Source: Kasverantwoording Djolotigo, 1929 -1939.

If we assume that households of labourers consist of a working father, a working mother and at least one working child, then on average a working child (below 12 years old) contributed $4.6 \%$ on average to the household income during the years 1929-1939. If more than one child was working which was often the case - their contributions could reach almost one fifth of the household budget. Apart from the contribution to household revenues, the work trained the plantation kids for future jobs at the plantation and to be economically independent at a later age without curtailing their right to play. Parents and the local society highly stimulated children to work. Work made them proud and it offered them the opportunity of showing to be a good child; capable of working, earning money and helpful to parents.

After reaching the age of about 11 to 12 years old - often before their first menstruation - girls followed the path of their mother and older sisters and started off tea picking. They started as soon as they were strong enough to carry a burden of ten to fifteen kilograms of tea leaves on their back in the hilly tea fields. The first two or three years they worked as apprentices under their mother or elder sisters or relatives supervision and their names were not officially listed in the plantation wage roster. When they grew bigger and strong enough to carry their own load of tea, they could be registered under their own name. Usually, this happened at the age of 13 to 14 years old. Foremen always welcomed new tea pickers as they would increase the total picking labour force and increase production. Grandma Wi told her experience again:

Well before my first menstruation, I joined my mother in the teafields and stopped playing. It was heavy work, but I liked it, I was strong [Giggling]. There was always work to do. In the beginning, the leaves I picked were added to those of my mother. Later on, when I married, I kept the money for myself.

Shoots picked by apprentices would be pooled together, later on mothers and daughters would divide the picking wage accordingly or mothers gave some small money to the children. Data on the real earning of apprentice tea pickers is not available, but observations in the 1970s and 1980s point out that on average the picking of young girls aged between approximately 12 to 14 years old were around one third to half of that of full fledged tea pickers. As time passed by, the apprentices' skills increased and their picking capabilities gradually improved. 
Combined with the earnings of the children, the total income of Jolotigo's labouring families in the 1920s and early 1930s was quite good. In general, women and daughters could sustain household needs nicely with their own income. ${ }^{15)}$ In the living memory of Jolotigo people, the pre-war era was a golden period. Their subsistence need was well covered and there was still some money left for other expenditures. Moreover housing was provided for free. With that level of earning and housing facilities, Jolotigo labourers in Puwoko could afford a self-indulging lifestyle. Rather than preparing their own meals, most labourers had their meals in the food stall. Spending money on ronggeng was almost a rule among men. Gambling was adopted practice both by men and women. Some men consumed and got addicted to opium that was available from the nearby towns of Doro and Bandar.

For landless farmers and poor households with limited access to farmlands, the plantation offered a good source of cash. Even more, if wife and children could add to the income of the household. The Jolotigo tea pickers came predominantly from the lowest social layers in the surrounding villages. Tea picking in the plantation just suited the needs of the impoverished villagers who needed alternative sources of income. The work was basically paid by piece and unrestricted by long-term contracts. It allowed the female labourers the necessary flexibility to move between farmwork in the village, household chores and coolie work in the plantation. These labourers were relatively free and often prospered by the combination of agriculture and a plantation wage. The plantation management was satisfied with this arrangement as long as enough labourers were working on a permanent basis.

The new labour legislation of 1925 , based on the ILO convention of 1919, which forbid the employment of children below 12 years of age, did not alter anything to the employment of children in the plantations. It only applied for children working in factories, not for those working in agriculture. Also for the plantation factories, exceptions were made, although the labour inspection tried to convince plantation owners not to employ workers in the factories. White (2004: 94) quotes from labour inspections cited in one of the Volksraadstukken (1925: 4):

"Labour Office officials made repeated visits to tea factories to convince them that they could easily do without the labour of children under
12 , which was in any case not often used inside the factories; in one factory which did make widespread use of children, calculation of the costs of replacing children by adults showed that production costs would increase only by one-tenth of one cent per pound of tea."

During the depression of the 1930s, tea picking served as an economic safety net for farmer households in Jolotigo and nearby hamlets. The decade of crisis was marked by a shortage of cash and many people in the lowland lost their job. Due to the mass lay-off and difficulty to earn cash, the number of tea pickers increased from less than 200 in 1932 to more than 400 in 1938, while in the same period, the size of Jolotigo's tea fields remained stable between 350 and 400 hectares. ${ }^{16)}$ From a plantation viewpoint, the coming of more labourers was most welcome. Their presence would allow a more thorough tea picking without any increase in the plantation budget as tea pickers' wages were based on the quantity of leaves they harvested. Existing labourers were less happy to see all these newcomers. They prevented outsiders from entering. New tea pickers who entered the work in the 1930s were especially children from established tea pickers, siblings or kin. The tea picking working groups were basically closely knitted social groups and opportunities to join the group were normally saved for someone related to a member of the group. As the quantity of leaves in the 1930s was more or less stable, the same total amount of leaves had to be divided among more tea pickers.

Yet, it was the decrease of payment for every kilogram of leaves harvested, as a result of the poor economic condition of the plantation due to the economic malaise, rather than the increase of tea pickers that brought wages further down. In 1930, when the number of pickers was 160 , the average monthly wage for each tea picker was $f 7,29$. Some eight years later, in 1938, when the number of tea pickers had more than doubled to 411 , their average monthly wage was four times smaller, $f 1,63$. In 1939, it increased a little bit to $f 1,75$ while the number of pickers decreased to $362 .{ }^{17)}$

A monthly wage of merely $f 1.75$ might seem little, but with that amount a tea picker could still buy at least 80 kilograms of low quality rice. By the mid 1930s, the daily wage of a male plantation labourer was around $f 0.15$. With this wage, a labourer could earn $f 4.5$ if he worked thirty days in a month. Wages for child labour at this period were certainly lower than 
in the previous decades, around 60 cents per month for a boy and 30 cents for girl. All those earning pooled together would still form a decent household income. It allowed the labourers to maintain a good livelihood. How good their livelihood in the depression years of 1930s was, is clearly reflected from their ability to maintain their old lifestyle of regularly eating in the food stall, consuming mutton sate and gulai, as well as spending money for ronggeng and gambling. Grandma Karni recalled:

Those years were the best years of my life. We had plenty of food - often more rice than we could eat - and regularly we went to the market or to the plantation housing complex to eat sate or gulai. If we went to the market with 50 cents in our the pocket we already felt very rich as it was enough to buy bunches of goods. My parents also regularly bought new clothes and we had sweets.

\section{Wartime, Turmoil and Famine 1942-1970}

This golden era was coming to an end with the Japanese occupation in 1942 - "and not to come again", plantation elders nostalgically and repeatedly said to us during interviews. During the Japanese period, all Dutch overseers, the administrator and their families were taken to internship camps. The management of the plantation was handed over to a team of Indonesian caretakers, kaisha, who previously worked as foremen, technicians and clerks. All workers were forced to remain working at the plantation. Anyone who would decline orders of the occupation government would be severely punished or killed. The marketing of the plantation products were fully controlled by the occupying government. In return, every plantation received operational cost from the government. ${ }^{18)}$ For tea plantations, this operational cost was established at 28 cents for every kilogram of black tea and 26 cents for every kilogram of green tea (Dep. Penerangan, 1965, IV: 269).

Tea production in Jolotigo dropped drastically during the three and half years of the Japanese occupation. The European markets were out of reach, the local market was weak, and the government scheme to collect and redistribute plantation products did not work well. The shipments of tea from Indonesia to Japan in 1942 were insignificant, as Japan herself was a big tea producer. ${ }^{19)}$ Export to other occupied countries was limited too as the war in the Pacific had curtailed Japanese shipping capacity. The incomes of the Jolotigo plantation and its workers decreased as the plantation could not pay much of the wages. Most of tea and cinchona fields were neglected and soon they were covered by wild alang-alang grass. To maintain their subsistence needs, Jolotigo labourers cleared small corners of the plantation to cultivate vegetables and dry land staple crops, such as maize, cassava, sweet potatoes and taro. In late 1943 or early 1944, the occupation authorities ordered the plantation to convert part of its area to food crop production. A quarter of the harvest should be handed to the plantation kaisha for further delivery to the Japanese, the rest could be kept or sold. By late 1943, at least 104 hectares of Jolotigo's land was cultivated for food crops. ${ }^{20)}$ In this period, the working children simply shifted from tea production to agriculture as every hand was needed.

Relatively, the economic condition of Jolotigo during the Japanese time was not too bad. The plantation still received revenue, albeit in small quantities, from the occupation authorities and workers had sufficient food from the plantation fields. It was the months after the Japanese surrender and the proclamation of Indonesian Independence in August 1945 that were really difficult. The catering of production costs paid by the Japanese authorities now was gone and at the same time the government of the newly born republic was not yet ready to work on the country's economic sector. Since the last year of Japanese occupation, local markets had been very weak and even became weaker as international markets remained out of reach. Without money, without political-economic back up from the government, and without a market the Jolotigo plantation plunged into a virtual standstill. Labourers could not go anywhere else as there was no work and little safety. They survived from food production at plantations' land.

Work for wages came again to Jolotigo after the Dutch army managed to take the plantation back from the Indonesian army in 1947. The Dutch poured money into Jolotigo to rehabilitate the processing factory and the emplacement which was burned down by the Indonesian army and to put the tea fields back into order after years of negligence. By 1948, the production capacity of the plantation was renewed, but real wages remained very low. A casual labourer earned $f 0.50$ per day and a tea picker received less than that. In the meantime, the price of low quality rice had risen to close to $f 1$ per kilogram (cf. Soejono, 1953: 141). 
It was after 1948 that the jobs for children of pest control, moss cleaning and seed collecting were available again, and almost without delay a good number of children went back to the tea fields again. Wages for children were very small. For each kilogram of their picking, a tea picker received 1 cent and on an average they collected less than 20 kilogram of leaves per day. The price of low quality rice was around 35 cent per kilogram after 1950. Mirah recalled her days as an apprentice to her mother in the early 1950s:

My earning was less than one rupiah per day, not enough to buy even a kilogram of rice. Apart from a wage, every tea picker received from the plantation a ration of five kilograms rice and five litres of kerosene per month, but as an apprentice I got no ration. It was only for officially registered tea pickers. Of course, the wage was very small, but still it was better than no wage at all. I gave most of my wage to my mother, I kept just a few cents for my own pocket money.

The 1950s were again a difficult time. The poorest families with little or no land badly needed the labour of their children to stay alive. The tea pickers' and their husbands' wages were enough only to cover the food expenses. To ease the labourers' burden, the plantation company provided them with rations of subsidized rice. Each labourer received $5 \mathrm{~kg}$ of rice per month at half the market price. ${ }^{21)}$ Clothes were such a luxury that at most, they could afford to buy some just once in a year, before Lebaran.

No. No. There was no way for us to wear presentable clothes at work. Not like nowadays. Tea pickers always wear field boots and thick clothes when they set out to the tea fields. At that time our attire to work was not different from beggar's clothes. We worked bare footed, and clothed our body with old rags so full of patches, that it was often difficult to find the original piece (Mirah).

In the following years, the wages increased continuously, but apparently not fast enough to stay far ahead of the rising rice price. In 1952, average daily revenues for a male labourer were $\mathrm{Rp} \mathrm{1.90.} \mathrm{In}$ the following year, the rate increased to Rp 3 per day while the market price for a kilogram of low quality rice was $\mathrm{Rp} 2$. In 1952, Jolotigo labour force officially consisted of 198 male and 278 female workers. Apart of them, there were many others whose name were not in the plantations' official list, but who worked in the plantation anyway. In the next five years, inflation was a bit under control, although the labourers' wage still remained very low. By the early months of 1958 , on average, a tea picker received Rp 3,17 per day while the rice price was $\mathrm{Rp} 2,84$ per kilogram. ${ }^{22}$ Male labourers earned a bit better wages of about Rp 5 per day.

Yet the worse was still to come after the 1957 nationalisation of foreign owned plantations in Indonesia. "In terms of wages there was no difference between the time of the Dutch and afterwards. It was said that after their departure the plantation belonged to Indonesia, but for us, the tea pickers, it just remained the same. The wage remained too small to cover our livelihood ", Mirah continued. At the early 1960s rice became more difficult to get. The price of rice in 1961 increased from $\mathrm{Rp} 7$ to $\mathrm{Rp} 15$ per kilogram, while the tea pickers' daily wages got stuck between Rp 5 to 7.50 per day. Rice rations from the plantation were not enough to feed a family and it was hard to obtain food from elsewhere. In 1962/1963, a food crisis hammered the Pekalongan region - and many other regions of Indonesia as well. A plague of rats and successive droughts caused series of harvest failures. Lots of people in the southern areas of Pekalongan died of hunger. ${ }^{23)}$

To help their labourers, the plantation increased rice rations to $10 \mathrm{~kg}$ per month for each registered tea picker and seasonal labourer, while regular workers received an extra ration of five kilograms for every child. This certainly reduced the labourers burden, but still it was below minimal subsistence needs. Salted or fermented sea fish, the labourers' traditional side dish and the almost only source of protein, was hard to buy as most of their income was spent on rice. Labourers substituted rice with maize and when maize became too expensive, they consumed aren palm sago (gelang). Finished from their tea harvest work, the tea pickers and their children would spend time in the forest to collect wild vegetables (ramban). In the dry season children as well as labourers picked bitter tasting rubber tree seeds. They boiled them over and over again to drive out the poisonous bitter taste. The boiled rubber seeds, blebar, were eaten as supplement to small quantities of main staples just to give the stomach a filled feeling. During the rainy season, people set up simple traps to catch protein rich crickets and young termites as a side dish. 


\section{Schooling and Technological Change}

Since the early 1950s, the plantation company had opened a three years primary school in Puwoko to provide education for the children of labourers. All children of schooling age (6-8) were obliged to attend the school. Upon completing Puwoko three years school they might continue to finish their primary education in Doro for another three years. Sometimes there was a truck available for the children to go to Doro, but most of the time they had to cover the $8 \mathrm{~km}$ along plantation roads barefoot. Only a handful of labour families were determined enough to send their children to finish their six years primary education.

The combination of a general labour shortage at the plantation and poor household earnings pushed labour families to send their young children ( 8 years and above) to work. But this time, children were forced to work out of sheer poverty and earnings remained meagre. Like in the previous decades, the children were employed for manual pest control, moss cleaning and seed collecting. It was in the 1960s that the number of child labourers reached its peak.

The number of working children started to decline slowly in 1968 , when the plantation company extended the old three years primary school to the national standard of six years and established an additional three years vocational junior high school named Sekolah Pembangunan Masyarakat Desa. As a result, the number of working children in Jolotigo decreased and they started to work at a later age. Still children dropped out of school at an early age or stayed at home regularly to help their parents earn cash in the tea fields as household incomes remained close to subsistence, but year after year, these numbers were significantly lower.

A further decline in the employment of children occurred in the early 1970s through the introduction of chemical pest control and the vegetative reproduction method for tea plants. Chemical pest control abolished the seven-decade-old child labour job of manual pest control. This new way of pest control involved specialised labourers and dangerous chemical substances as well as heavy tank spraying, too heavy for a child to carry up and down hilly tea fields. The vegetative reproduction of tea plants, stek daun, replaced the old method of gathering and selection of tea seeds. The new method had to be carried out carefully by experienced labourers, and children were no longer needed nor helpful. Helping the mother or sister in tea picking therefore was the only job which remained open for girls. Boys could now only start to work as labourer when they were at least 12 years old and preferably 14 years old and were strong enough to join the tasks of adults such as the cleaning of wild grass beneath the tea shrubs, babat.

Tea pickers often brought their small daughters along to the tea field because there was no one taking care of their children at home. So it was better to take them to work, they thought, as the children could play around in the tea field and start learning how to work by observing and mimicking what their mothers were doing. Later on, when the girls entered school at the age of 6, they still came along with their mother during school holidays. Kartumi, a tea picker of 48 years old, told us about her childhood:

Since I was in the fourth year of primary school every school holidays I joined my mother to the tea field. I picked tea leaves and pooled my picking with the leaves of someone else, not my mother. In this way, I earned a small amount of money and used it to buy writing books and pencils. I earned more money during long vacations as well, because I could work for the full three weeks.

The plantation company did not object the involvement of small and young girls in tea picking since it cost them nothing. The girls were not listed in the company list of workers so they would be paid according to the result of their picking without any health and other benefits. Foremen were happy with these girls, since they would increase the total harvest from the foremen' blocks without any need of administrative procedures. Moreover, the induction of young girls to their working gang would ensure a smooth transfer of skills from experienced tea pickers to the new ones without any need of a special training program. Once trained as a tea picker, they would not easily go away, as they had not acquired any other skill. Tea picking mothers were often glad as well as because by taking a job as tea picker their children would start earning their own income and ease households economic burden while they stayed within sight. Finally, the young girls themselves were also happy, by taking a plantation job, they felt less dependent on their parents and useful to their family.

From the 1970s onwards, structural changes in the Indonesian society took place. An important change in Jolotigo was the improvement of workers' welfare. A semi-official effort to improve the welfare of the labourers and to keep the plantation community tied to plantation and governmental 
control, took place in the early 1970 s, when the plantation company ordered the establishment of a worker cooperative in every plantation. In 1972, a cooperative named Giri Makmur, Prosperous Hill, was established in Jolotigo. ${ }^{24)}$ In the beginning the cooperative just opened a credit service and a retail shop selling rice and personal working equipments such as plastic boots, raincoats and pruning machetes. Out of the annual profit the cooperative provided a few scholarships for bright children of labourers, and later, when developed into a credit union, it usually loaned workers the money to settle their children's schooling fees, fees for hospitalisation and other pressing needs.

The vast expansion of business and private sector companies in the Indonesian cities in the 1980s gradually changed the view of plantation people that life was better at the plantation premises. Those families who survived for years due to the work and the supplies of the plantation and the additional labour of their children gradually understood that the future of their children might be better secured beyond the small world of the plantation. Some workers started to send their children to high school in Pekalongan. With their limited wage, it was not easy for the labourers to send their children to high school, but they were determined. Most of these kids finished senior high school. Some of them returned to the plantation as foremen, technician or administrative clerk, others remained in Pekalongan or moved to other cities. Nevertheless, vertical mobility at the plantation remained very low.

Still most children did not continue after primary school tough. As a result, the majority of girls, would go into tea picking right after finishing their primary school. "It was better than sitting idly, doing nothing at home, only waiting to be proposed by a boy", Bariyah explained her reason of picking tea. Many of them, however, did not stay long in tea picking, the expansion of job opportunities in the cities, especially as domestic helpers, lured them to migrate to Pekalongan, Semarang, Tegal and other cities. They followed girls from neighbouring villages who had started to migrate somewhat earlier. In Pekalongan, they often worked for several years as a domestic worker or shop assistant, and then they moved back to Jolotigo to marry and become a tea picker again. Many of these girls, who already went away at an early age (14 - 15 years old) ended up in low paid jobs as domestic worker and sometimes worked under very unfree conditions. Nevertheless, they preferred these jobs in town instead of working at the plantation all of their lives. In the 1980s, boys also started to migrate to the cities as an alternative to wage labour at the plantation, but their number was much lower than that of the girls and they tend to migrate more permanently. Once left, Jolotigo boys rarely returned.

\section{The Opening Up of the Plantation Community}

By 1990, children have almost totally disappeared from the labour process at the plantation and go to school in town at least till the age of 15 or 18 . Almost all boys and most of the girls finish junior high school. Availability of regular transport and later on 'motor bike revolution' opened the plantation children access to high school in towns. This development follows the same development in other parts of rural Java (see White 2012). Instead of offering a nice additional income for the household, they now form one of the major expenses of households. The few school dropouts, still start to work at a young age, but generally after 15 years of age, and many end up as domestic worker or construction worker in Semarang or Jakarta - or more often nowadays, abroad in Malaysia or one of the Gulf states. The thrill of migration and working in another country, and the chance to bring home large amounts of money, largely seem to compensate for the risk of being mistreated, raped, cheated, and exploited.

The almost total decline in working children at the Jolotigo plantation came about largely not because of changing in labour laws. During the highdays of child labour, no improved child labour laws were issued. When child labour finally disappeared, its was not due to improved legislation which steered this effort. Children now go to secondary school in larger numbers and migrate to far away places due to the availability of better schooling and a more diversified labour market. They no longer provide additional income to the household and due to migration they will also not automatically contribute to the old age security of the parents.

In accordance to the Worker Law No.3/ 1992 (see Odang, 1992), in January 1993 the plantation company introduced a new policy that was deeply appreciated by the formally employed labourers. From January 1993 onwards all regular labourers who had worked for more than twenty years and had entered retirement at age 55 would receive a retirement benefit plus bonus. ${ }^{25)}$ The bonus could be quite large. 
A labourer with contract who had been working for 35 years would receive a gratification of at least forty five times his last wage, while the fixed retirement wage is sixty percent of the last basic wage. "It is not much", retired foreman Domo said, "But it helps us to live our retirement with dignity". This retirement benefit, however, was not enjoyed by the majority of Jolotigo workers who had worked at the plantation since childhood. This was a further disappointment for those who claimed themselves as "native" Jolotigo workers, the descendants of those who came to the plantation as coolies at the dawn of the $20^{\text {th }}$ century. Most of the workers who gained a good position or promotion to the rank of regular workers were newcomers who came to the plantation from outside with good education.

A surge in the number of regular workers took place in the late 1990s at the volatile years of Reformasi. Jolotigo workers staged a series of demonstrations in demand for improvement of their labour status and socio-economic condition. The result of this demonstration and some other talks with the administrator was that in 1998 some 65 senior foremen and labourers received a formal contract. Further promotion took place in the following years and by 2001 there were 246 labourers with a contract in Jolotigo. ${ }^{26)}$ Afraid that the labourer would develop or join "uncontrollable" labour unions, in 1999 the plantation company initiated Serikat Pekerja Perkebunan (SP Bun), the Plantation Worker Union. The SP Bun task was to promote and represent the workers interest vis a vis the company and its policy. Together with units of SP Bun from other plantations, Jolotigo's SP Bun was organized into Gabungan SP BUN PTPN IX, the Union of State Plantation Company Nusantara IX's Worker Unions. In this way the plantation company had provided a safe and controllable arena for the labourers to speak up and promote their interest. Daily labourers, though, were not represented. In 2000 the SP Bun PTPN IX and the plantation company signed a working agreement, Kesepakatan Kerja Bersama. ${ }^{27)}$ Some arrangements extended to the daily labourers, now they were entitled to an annual and holiday bonus, working clothes, and retirement benefits. In 2001 the Plantation Company Director issued Decree No. 246, which stated that the minimum age of the plantation workers should be 18 years. ${ }^{28)}$

Further growth of city based industry and the service sector in the late 1990s expanded the migration areas of Jolotigo girls. Now, they not only go to other cities on Java, but also go to the other islands of Indonesia and to foreign countries. Many young girls, right after finishing their primary school or junior high school, determinedly left their parents or families to widen their worldview or try their luck in the cities or abroad. There are many success stories among these girls and young women, as most of them were able to send home a good amount of money to renovate houses, to buy motorcycles, or to buy land. Yet, there are also some sad stories of lost people who never send any information, young women who came home penniless, in poor condition due to physical and mental abuse, who died abroad, or who got pregnant or raped by their master (Killias 2017). All these risks however, are considered acceptable to many girls and their parents, considering the alternative they have in Jolotigo; tea picking.

Foremen Mat told us about the daughter of a friend who went to Saudi after senior highschool. 'In the holi land (tanah suci), she got raped and became pregnant. When they discovered she was pregnant, she was immediately thrown out of the country. She did not bring money home and her parents still have a debt at the recruitment agency. Now she picks tealeaves again, while her sick mother has to take care of the baby. That child really looks like an Arab'.

Wini, the daughter of another foremen, finished school for tourism. At the age of 17, she decided to go to Manado (North Sulawesi) to work in a beauty parlor. She met a lady in Pekalongan who offered her a good earning. Moreover, she would pay for her trip. After a year she sends a message from Batam, next to Singapore that she is working in the tourist industry there. After two years, she came back to the village 'without any money, ill and very tired'.

By early 2000, the wage for tea picking had increased to Rp 125 per kilogram in adjustment to the inflation rate and it has further increased to $\mathrm{Rp}$ 330 in 2009. On an average, Jolotigo tea pickers are now capable to pick 473 kilograms of tea leaves per month. In 2000, that yielded them an average wage of $\mathrm{Rp} 76.782$. The price of low quality rice in 2000 was around $\mathrm{Rp} 1.500$ per kilogram, so, a tea picker earned around $50 \mathrm{~kg}$ of rice per month. This is just enough to cover the livelihood needs of two persons at Sajogyo's poverty line. In 2002, the wage of tea pickers was increased rather substantially to Rp 236 for every kilogram of tea leaves. At this rate, a tea picker could 
earn Rp 110.000 per month, but this increase did not really improve the labourers' purchasing power, since during that same period, the price of low quality rice had increased to $\mathrm{Rp} 2.000$ per kilogram. Whether Rp 76.782 or Rp 110.000 , the monthly wage just allowed a tea picker to buy 50 to 55 kilogram of low quality rice per month. The monthly wage at this rate is certainly not attractive to the young and better educated girls. For them, the brightly lighted cities remain more attractive, even if working there might involve some form of dependency or bondage or even contain the risk of severe coercion or some form of forced labour.

\section{CONCLUSIONS: THE DEMISE OF CHILD LABOUR AND SHIFTS IN UNFREE LABOUR}

Although wages have never returned to pre-war levels for tea pickers, working conditions and social services of employees have improved substantially at the Jolotigo's tea plantation. Nowadays, a number of alternatives have become available both for boys and girls. Due to better education, at least some of these opportunities are available for the children of former plantation workers. Moreover, child labour has disappeared from the plantation almost completely and the lives of children has improved substantially. The gradual decline of children's jobs after 1960 meant a decline of children's contribution to household revenues, but it also meant a prolongation of their childhood. As a result children started to marry later and stayed at home longer. Their childhood has been extended and their options have been increased. Nevertheless, for some plantation children, forms of bonded labour seem to have been replaced by new forms of bondage as a result of migration to the city or abroad.

Contrary to popular beliefs, improved legislation and the establishment of child labour laws do not explain the early continuation and the later demise of child labour at the tea plantation on Java. Children provided not only a supplementary source of income for the household, but for years, they made up an essential part of the plantation economy itself. Only after important technological changes, societal change, a substantial improvement of household incomes, and the mass availability of public schooling, the numbers of working children started to decline. Crucial mechanisms in these processes have been the change in labour demand from the plantation, the opportunity costs of working elsewhere, the availability of education and a general rise in household incomes which made migration possible. From a policy perspective, these changes might seem rather paradoxical. In the early decades of the $20^{\text {th }}$ century and the years after independence, children remained working despite improved legislation on working children (major laws passed in 1925, 1951 and 1997), while the demise of child labour in the 1980s took place despite important legal changes or improvements in (inter)national legislation.

The far reaching conclusion from this case study is that changes in child labour in industrial agricultural production systems are rather to be achieved by focussing on improving family incomes and the availability of cheap, universal education, than by the improvement of labour laws and the implementation of these laws. In developmental terms: rather focus on the improvement of rural livelihoods, rural welfare systems, and technological production regimes, than on the rights and obligations of right bearers and right givers. Moreover, we learn that some forms of child labour can disappear, but others might well reemerge at other places and under other conditions as a result of on-going and emerging new inequalities at a global scale. Some of Jolotigo's children, children of formerly bonded labourers, are now bound and caught up in unfree labour arrangements in Semarang, Jakarta, Malaysia or in one of the Gulf states. They are found in domestic labour, construction work, in prostitution, as shop assistant, or working as a street trader in someone else's business. Not all of these workers can simply be regarded as victims of forced labour-they themselves will not say so anyway. They have not been trapped or cheated into these labour arrangements. On the contrary, the promise of high earnings, a chance of a better future, the thrill of a different life, definitely has stimulated them to enter in these relations and accept any unfavourable aspects of these jobs. Has it ever been different?

\section{ENDNOTES}

1) Javanese labourers often brought their women with them once plantations were well established and started production. Moreover, at the end of the 19th century, the colonial government permitted women to be contracted as labourers independently (See Breman 1987: 89, 122). Their lower wages made them attractive workers, their children could be paid even lower wages. Moreover, bringing women along strengthened the ties of workers to the plantation and decreased unrest among the workers 
and the risk of running away.

2) The ILO speaks of forced labour. We prefer to use the term unfree labour. Forced labour hints more at the coercion part of the definition, while unfree labour as a general term indicates any form of labour being restricted in some way, such as: bonded labour, contract labour, indentured labour, trafficking, etc. Both terms include the labour of adults as well as children's. Unfree labour refers to a gliding scale of un-freedom for the labouring person. We then refer to the lack of freedom to chose one's employer, to chose from alternative or competitive labour conditions, limitations in geographical mobility, limitations due to legal restrictions and penalties (as in slavery and contract or indentured labour contracts), unfreedom due to financial hindrances (i.e. debt bondage), and a general lack of freedom to engage in - and end contracts at ones own will and time (definition loosely derived from Baak (1997: 430). Unfree labour is not a fixed condition, it refers to a gliding scale of unfree labour forms containing one or more of the above elements. Child labour is often embedded into and related to other forms of unfree labour parents or caretakers are entangled in.

3) In 1874, in The Netherlands, the first laws for the regulation of child labour (the so-called child law of Van Houten) were administered.

4) Countries were actually encouraged to modify the 1919 ILO convention to suit to local and regional conditions. As a result, many sectors, especially agriculture and agricultural estates, were not included in the regulations.

5) The Netherlands Indies Agricultural Union reported objections to the proposed prohibition from many upland plantations, including some rubber estates but particularly the tea estates, which employed children in many kinds of work (White 2004).

6) The bark of cinchona trees is used for the production of quinine - an anti-malaria medicine.

7) The wages among those types of labourers did not differ much, but there were large differences in social welfare. Javanese indentured labourers, deployed mainly in the East Sumatran rubber and tobacco plantations, were subjected to a penal sanction when they did not fulfil their contract. They were often treated badly by the plantation management. Free labourers in the Javanese plantations received a far more human treatment from their employers (Breman, 1989; Clerkx and Wertheim, 1991) as the plantation management did almost everything to bind a good labour force to the plantation.

8) NA. Cultuurmaatschappij Djolotigo. No. 15. Jaarverslaagen 1920 - 1939.

9) From month to month, the number of labourers kept changing in accordance to the plantation need. In August 1891, for instance, the number was 82 male and 37 female while in October it was 126 male and 74 female (NA, NHM, 1824 - 1964. No. 7953 Koffieonderneming Djolotigo).

10) NA, NHM, 1824-1964. No. 7953 Koffieonderneming Djolotigo.

11) NA, NHM, 1824-1964. No. 7953 Koffieonderneming Djolotigo.

12) The normal labour demand was one tea picker for a hectare of tea. By the early 1900s Jolotigo's tea fields amounted around 100 hectares and as years passed by, the size was steadily enlarged (de Bussy, 1903; 1915).

13) Although the year of birth often was not registered in these years, the age of the children is generally referred to as $8-12$. Girls started working years before their first menstruation.

14) See also: (Sajogyo 1986).

15) NA, Cultuurmaatschappij Djolotigo. No. 3. Kasverantwordingen, 1927-1931; Mansvelt and Creutzberg (1978: 57-8).

16) NA. Cultuurmaatschappij Djolotigo. No. 3.Kasverantwordingen, 1932- 1939; De Bussy, 1935, 1939.

17) NA, Cultuurmaatschappij Djolotigo. No. 3.Kasverantwoordingen, 1932-1939.

18) Waseda University Library, Nishijima Collection: AG 14; JV2-16.

19) Waseda University Library, Nishijima Collection: AG 1-7.

20) PNP XVIII Jolotigo: Map of Doro District, 1944.

21) See also "Rini Buruh Kebun" in WS, Vol. IV. No. 11-12.

22) NA, Cultuurmaatschappij Djolotigo. No. 17. "Enige interessante".

23) SM, July 16, 1962; May 15, 1963; June 4, 1963.

24) PTPN IX Kebun Jolotigo, RAT Koperasi Giri Makmur 2002.

25) PTPN IX Kebun Jolotigo, Surat Keputusan Direksi No. PTPN IX.0/SK/050.

26) PTPN IX Kebun Jolotigo, Laporan Realisasi 2000; 2001.

27) PTPN IX Kebun Jolotigo: Kesepakatan Kerja Bersama.

28) See also Surat Keputusan Direksi PT Perkebunan Nusantara IX (Persero) No. 021/2004.

\section{REFERENCES}

De Arbeidscommissie (1920). Berita Komisi Perihal Koeli Tentang Minimum Oepah Jang Ditetapkan Dalam Oendang-Oendang Oentoek Pengambil Kerdja di Tanah Djawa dan Madoera. Batavia: 
De Arbeidscommisie.

Baak, Paul E. (1999). About Enslaved Ex-Slaves, Uncaptured Contract Coolies and Unfreed Freedmen: Some Notes About 'Free' and 'Unfree' Labour in the Context of Plantation Development in Southwest India, Early Sixteenth Century-Mid 1990s. Modern Asian Studies, 33, 121-157.

Baak, Paul E. (1997). Enslaved Ex-Slaves, Uncaptured Contract Coolies and Unfree Freedmen: "Free" and "Unfree" labour in the context of plantation development in Southwest India. In Free and Unfree Labour: The debate continues, edited by T. Brass and M. Van der Linden. New York: Peter Lang AG.

Van den Berge, Tom (1998). Karel Frederik Holle. Theeplanter in Indie 1829-1896. Amsterdam: Bakker.

Breman, Jan (1983). Control of Land and Labour in Colonial Java. A case study of agrarian crisis and reform in the region of Cirebon during the first decades of the 20th century. Vol. 101, Verhandelingen van het Koninklijk Instituut voor Taal-, Land- en Volkenkunde. Leiden: KITLV Press.

(1987). Koelies, planters en koloniale politiek: Het arbeidsregime op de grootlandbouwondernemingen aan Sumatra's Oostkust in het begin van de twintigste eeuw. Vol. 123, Verhandelingen van het Koninklijk Instituut voor Taal-, Land-, en Volkenkunde. Dordrecht: Foris Publications.

(1988). Wild Man in Bondage, Colonial Mentality in Early 20th-Century Sumatra. Bijdragen Tot De Taal-Land- En Volkenkunde, 144(1), 19-43.

(1989). Taming the Coolie Beast. Plantation society and the colonial order in Southeast Asia. New Delhi: Oxford University Press.

(1992). Koelies, Planters en Koloniale Politiek: Het arbeidsregime op de grootlandbouwondernemingen aan Sumatra's Oostkust in het beginv ande 20e eeuw., Verhandelingen van het Koningklijk Instituut voor Taal-, Land-en Volkenkunde 123 [Third, revised edition]. Leiden: KITLV Press.

Breman, Jan, and E. V. Daniel (1992). The Making of a Coolie - Conclusion. Journal of Peasant Studies, 19(3-4), 268-295.

De Bussy, J.H. (1888-1939). Handboek voor cultuur-en handels-ondernemingen in Nederlandsch-Indie. Amsterdam: J.H. de Bussy

Dep. Penerangan (1965). 20 Tahun Indonesia Merdeka. Vol. IV. Jakarta: Dep. Penerangan.

Clerkx, Lily E. and Wertheim, Wim F. (1991). Living in Deli. Its society as imaged in colonial fiction.
Amsterdam: Free University and Centre for Asian Studies Amsterdam.

Collier, William (1981). Declining Labour Absorption (1878-1980) in Javanese Rice Production. Kajian Ekonomi Malaysia, 17, 102-136.

Jones, Gavin W. (2001). Which Indonesian Women Marry Youngest, and Why? Journal of Southeast Asian Studies, 32(1), 67-78.

De Kat Angelino, P. (1936). Some Remarks on the Wages Paid in the Netherlands Indies. The Institute of Pacific Relation.

Emmer, P. C. (1986). "The Meek Hindu: The Recruitment of Indian Indentured Labourers for Service Overseas, 1870-1916" in P.C. Emmer (ed.) Colonialism and Migration: Indentured Labour Before and After Slavery. Dordrecht: Martinus Nijhoff.

Galenson, Donald (1984). "The Rise and Fall of Indentured Servitude: An Economic Analysis" in Journal of Economic History, XLIV(1).

Geertz, Clifford (1973). The Interpretation of Cultures. New York: Basic Books.

Van Keesteren, A. J. (1931). "Plukloonbepaling in de Theecultuur" in ALNI. No 15/16.

Killias, Olivia (2017). Follow the Maid. Copenhagen: NIAS Press.

Knight, Roger (1993a). Colonial Production in Provincial Java. Amsterdam: VU University Press. - (1993b). "Gully coolies, weed-women and snijvolk. The sugar industry workers of North Java in the early twentieth century" in J. Th. Lindblad (ed.), New challenges in the modern economic history of Indonesia. Leiden: Programme of Indonesian Studies.

Koperberg, L. (1917). "Geneeskundige verzorging der Inlandsche Arbeiders" in Koloniale Studien. No. 8, 1917.

Lieten, G. K., and Ben White, eds. (2001). Child Labour: Policy options. Amsterdam: Aksant Academic Publishers.

Mansvelt, W.M.F. and P.J.D. Creutzberg (eds.) (1978). Changing Economy in Indonesia, 4. Rice Prices. The Hague: Nijhoff.

Odang, Muchtar (1992). Rujukan Melaksanakan Jaminan Sosial Tenaga Kerja: Undang-Undang Nomor 3 Tahun 1992, Peraturan Pemerintah Nomor 33 Tahun 1977 (Astek). Jakarta: Agung.

Sajhau, Jean-Paul and Jurgen von Murat (1987). Plantations and plantation workers. Geneva: ILO

Sajogyo (1996). Garis Kemiskinan dan Kebutuhan Minimum Pangan. Jogjakarta: Aditya Media.

Sajogyo, William L. Collier, ed. (1986). Budidaya padi di Jawa. Edited by W. L. Collier, Pembangunan Pedesaan. Jakarta: Gramedia. 
Semedi, Pujo. (forthcoming). Drinking with the Devil: Plantation Community and World Capitalism in Java, 1870-2000. London: Routledge.

Soejono (1953). Pedoman Perburuhan. Djakarta: NV. V.H. van Dorp \& Co.

Wal, Sanne van der. (2008). Sustainability Issues in the Tea Sector: A comparative analysis of six leading producing countries. Amsterdam: SOMO - Centre for Research on Multinational Corporations.

Wertheim, W.F. (1956). Indonesian Society in Transition. The Hague / Bandung: W. van Hoeve Ltd.

White, Ben (2004). Constructing Child Labour: Attitudes to Juvenile Work in Indonesia, 1900-2000. In Labour in Southeast Asia: Local Processes in a Globalised World, edited by R. Elmhirst and R. Saptari. London: Routledge.

(2012). Changing Childhoods: Javanese village children in three generations. Journal of Agrarian Change, 12(1), 81-97.

\section{Archival Sources}

\section{Nationaal Archive, The Hague}

Cultuurmaatschappij Djolotigo. No. 3. Kasverantwordingen, 1932- 1939;

Cultuurmaatschappij Djolotigo. No. 3 . Kasverantwordingen, 1932-1939.

Cultuurmaatschappij Djolotigo. No. 15. Jaarverslaagen 1920 - 1939.

Cultuurmaatschappij Djolotigo. No. 3. Kasverantwordingen, 1927-1931;

Cultuurmaatschappij Djolotigo. No. 17. "Enige interessante".

Koloniaal Verslag (KV), 1910, Bijl. ZZ

NHM, 1824 - 1964. No. 7953 Koffieonderneming
Djolotigo).

NHM, 1824 - 1964. No. 7953 Koffieonderneming Djolotigo.

NHM, 1824 - 1964. No. 7953 Koffieonderneming Djolotigo.

NHM, 1824 - 1964. No. 7953 Koffieonderneming Djolotigo.

\section{PTPN IX, Semarang}

PNP XVIII Jolotigo: Map of Doro District, 1944.

PTPN IX Kebun Jolotigo, RAT Koperasi Giri Makmur 2002.

PTPN IX Kebun Jolotigo, Surat Keputusan Direksi No. PTPN IX.0/SK/050.

PTPN IX Kebun Jolotigo, Laporan Realisasi 2000; 2001. PTPN IX Kebun Jolotigo: Kesepakatan Kerja Bersama.

PTPN IX Surat Keputusan Direksi PT Perkebunan Nusantara IX (Persero) No. 021/2004. Tentang Ketentuan-Ketentuan yang Berkaitan dengan Hubungan Kerja dan Jaminan Sosial Karyawan Divisi Tanaman Tahunan.

\section{Waseda University Library}

Nishijima Collection: AG 1-7.

Nishijima Collection: AG 14;

Nishijima Collection: JV2-16.

\section{Suara Merdeka Daily, Semarang (SM)}

July 16, 1962;

May 15, 1963;

June 4, 1963.

Warta Sarbupri, Jakarta (WS)

WS, Vol. IV. No. 11-12. "Rini Buruh Kebun” . 